\title{
PELATIHAN PEMBUATAN DAN PENGGUNAAN ALAT PERAGA MATEMATIKA PADA MATERI LUAS DAERAH BELAH KETUPAT DENGAN PENDEKATAN LUAS DAERAH SEGITIGA
}

\author{
Jayanti Putri Purwaningrum ${ }^{1)}$, Latifah Nur Ahyani²) \\ 1)Pendidikan Matematika, FKIP, Universitas Muria Kudus, Kudus, Jawa Tengah, Indonesia \\ 2)Psikologi, F.Psikilogi, Universitas Muria Kudus, Kudus, Jawa Tengah, Indonesia \\ Corresponding author : Jayanti Putri Purwaningrum \\ E-mail : Jayanti.putri@umk.ac.id
}

\section{Diterima 19 Juni 2020, Direvisi 22 Agustus 2020, Disetujui 24 Agustus 2020}

\begin{abstract}
ABSTRAK
Guru-guru di SD 4 Puyoh terbiasa mengajar dengan pola teacher centered sehingga mereka merasa kesulitan dalam mengembangkan berbagai kemampuan matematis siswa. Tujuan dari kegiatan pengabdian ini adalah untuk memberikan pengetahuan dan praktik serta membantu para guru dalam mengembangkan berbagai kemampuan matematis siswa dengan menggunakan media pembelajaran berupa alat peraga matematika pada materi luas daerah belah ketupat dengan pendekatan luas daerah segitiga. Dengan adanya pengabdian ini, diharapkan dapat sangat menunjang guru-guru di SD 4 Puyoh dalam meningkatkan berbagai kemampuan matematis siswa SD. Hasil dari kegiatan pengabdian ini yaitu guru-guru di SD 4 Puyoh Kabupaten Kudus dapat mengenal dan memahami strategi (teori) dan media pembelajaran yang dapat digunakan untuk meningkatkan kemampuan matematis siswa. Selain itu, guru-guru juga dapat merancang dan menyusun media pembelajaran berupa alat peraga sebagai media pembelajaran matematika salah satunya pada materi luas daerah belah ketupat dengan pendekatan luas daerah segitiga. Guru-guru di SD tersebut pun memperoleh pengetahuan dan gambaran simulasi dan praktik pembelajaran dengan menggunakan media pembelajaran berupa alat peraga sebagai media pembelajaran matematika pada materi luas daerah belah ketupat dengan pendekatan luas daerah segitiga untuk meningkatkan berbagai kemampuan matematis siswa.
\end{abstract}

Kata kunci: matematika; media; alat peraga.

\begin{abstract}
The teachers at SD 4 Puyoh are accustomed to teaching with teacher centered patterns so that they find it difficult to develop various mathematical abilities of students. The purpose of this dedication activity is to provide knowledge and practice as well as assist teachers in developing various mathematical abilities of students by using learning media in the form of mathematical teaching aids on the material of rhombic areas with the area approach of triangular regions. With this dedication, it is expected to greatly support the teachers at SD 4 Puyoh in improving various mathematical abilities of elementary students. The result of this community service activity is that teachers at SD 4 Puyoh Kudus Regency can get to know and understand strategies (theory) and learning media that can be used to improve students' mathematical abilities. In addition, teachers can also design and compile learning media in the form of teaching aids as a medium for learning mathematics, one of which is on the wide area of the rhombic area with a triangle area approach. The teachers at the elementary school also gained knowledge and illustration of simulations and learning practices by using instructional media in the form of teaching aids as a medium for learning mathematics in the wide area of rhombic areas with a wide area approach to triangles to improve a variety of mathematical abilities of students
\end{abstract}

Keywords: mathematics; media; props.

\section{PENDAHULUAN}

Pengabdian ini merupakan pengabdian lanjutan yang telah dilakukan sebelumnya oleh tim pengabdi yang berjudul "Pendampingan Pembuatan dan Penggunaan CD Pembelajaran pada Gugus Sentana". Hasil evaluasi dan diskusi antara tim pengabdi dengan guru-guru di SD 4 Puyoh menunjukkan bahwa selain banyak dari guru-guru SD yang masih kesulitan dalam mengoperasikan komputer sehingga proses membuat $C D$ pembelajara menjadi terhambat. Guru-guru lebih memilih membuat media pembelajaran berupa alat peraga. Akan tetapi fakta di lapangan menunjukkan, guru- 
guru masih kesulitan dalam membuat dan menggunakan alat peraga matematika yang berbasis konstruktivis misalnya alat peraga penemuan konsep rumus luas daerah belah ketupat. Hal inilah yang menjadikan guru-guru di SD 4 Puyoh menginginkan adanya pendampingan pembuatan dan penggunaan media pembelajaran pada materi luas daerah belah ketupat.

Hal lain yang menjadi faktor pengabdian ini adalah, siswa terbiasa menghapalkan rumus luas daerah belah ketupat yaitu $\mathrm{L}=12 x d 1 x d 2$. Kedua, siswa juga terbiasa mendengar maupun membicarakan konsep luas akan tetapi sebenarnya mereka tidak tahu apakah sebenarnya pengertian luas daerah pada bangun datar. Ketiga, guru-guru masih kesulitan untuk mengajarkan matematika berbasis konstruktivis dimana siswa secara mandiri dapat menemukan konsep atau rumus matematika tanpa diberitahu oleh guru terlebih dahulu.

Pada hakikatnya, luas daerah bangun datar merupakan materi yang diajarkan mulai jenjang sekolah dasar sampai sekolah menengah pertama. Materi ini sangat berguna diantaranya adalah ketika seseorang ingin membeli tanah untuk membangun rumah. Hasil observasi dengan siswa, jika siswa diberikan pertanyaan, mengapa kalau membeli tanah tidak dihitung kelilingnya saja tetapi kita menghitung luasnya? Apakah arti sebenarnya keliling dan luas? Berdasarkan wawancara dengan guru, untuk menjawab pertanyaan tersebut masih banyak ditemukan miskonsepsi pada siswa dalam mengartikan luas maupun keliling bangun datar. Banyak siswa yang masih terbolak-balik dalam mengartikannya atau bahkan malah tidak tahu apakah makna dari keliling dan luas sebenarnya. Pada kenyatannya di lapangan, menurut hasil wawancara, guru di SD 4 Puyoh terbiasa menggunakan kata "Pokoknya rumusnya itu ya itu" ketika menjelaskan materi atau konsep matematika. Akibatnya, siswa terbiasa menerima rumus matematika seadanya untuk dihapalkan. Padahal, konsep matematika yang dipelajari oleh siswa SD tersebut sangatlah abstrak.

Menurut teori perkembangan kognitif Piaget, pada umumnya siswa SD berumur 6-7 tahun sampai 11-12 tahun dan berada pada tahap operasional konkret. Pada tahap ini siswa sudah mampu berpikir menggunakan kaidah logika walaupun hanya pada benda konkret yang ditangkap dari panca indra. Sehingga, pada saat mempelajari konsep matematika, guru sering diharuskan menggunakan alat peraga atau ilustrasi konkret dari dunia nyata dan menggunakan teknik analogi supaya materi yang dipelajari mudah dipahami. Dengan demikian, adanya alat peraga dapat menjadi salah satu alternatif agar siswa mudah belajar dan memahami konsep matematika.

Kedua, jika siswa diminta untuk membayangkan bentuk dari bangun datar belah ketupat dan diminta untuk mencari luas daerah tersebut, mereka akan merasa kesulitan. Di sinilah alat peraga akan berperan dalam menvisualisasikan bentuk dan cara mencari luas bangun datar berdimensi dua tersebut. Penggunaan alat peraga merangsang imajinasi siswa dan memberikan kesan yang mendalam ketika mengajar. Semua panca indera dan seluruh kesanggupan anak perlu untuk dirangsang, digunakan dan dilibatkan, sehingga mereka tidak saja mengetahui, tetapi juga dapat menggunakan dan mengaplikasikan apa yang dipelajari.

Ketiga, pada pokok bahasan luas daerah belah ketupat, siswa tidak hanya diharapkan dapat menyelesaikan masalah matematis tetapi juga dapat menemukan konsep luas daerah belah ketupat tersebut sehingga mereka bisa menemukan rumus $L=$ $\frac{1}{2} \mathrm{x} d_{1} \mathrm{x} d_{2}$. Untuk lebih mempermudah pemahaman siswa dalam menemukan konsep luas daerah belah ketupat maka bantuan media pembelajaran lain misalnya alat peraga dirasa perlu digunakan dalam proses pembelajaran. Harapannya, siswa mempunyai gambaran konkrit mengenai cara mencari rumus luas daerah belah ketupat sehingga hasil belajar siswa dapat meningkat.

Keempat, pada kenyataannya berdasarkan hasil wawancara, guru-guru di SD 4 Puyoh juga belum memiliki banyak pengalaman dalam pembuatan maupun penggunaan media pembelajaran berupa alat peraga materi luas daerah belah ketupat. Dalam proses belajar mengajar, guru-guru di SD tersebut terbiasa menggunakan metode ceramah, dengan kata lain, siswa hanya mendengarkan penjelasan dari guru saja sehingga pembelajaran menjadi kurang menarik. Selain itu, siswa juga kurang mendapatkan kesempatan untuk aktif pada kegiatan belajar mengajar.

Kelima, selama pembelajaran, penyampaian materi yang diberikan guru masih bersifat abstrak. Selain itu guru kerap sekali tidak menggunakan benda manipulatif dalam mengkonkrikan materi yang sifatnya abstrak. Guru-guru terbiasa berfokus pada buku paket dan siswa tidak dibimbing untuk menemukan sendiri rumus yang akan digunakan untuk menentukan luas daerah bangun datar melainkan hanya menerima materi yang 
disampaikan guru. Dengan demikian ada beberapa siswa yang dapat memahami dan ada pula siswa yang sama sekali tidak memahami apa yang dijelaskan oleh guru. Penyebab guru jarang menggunakan benda manipulatif dalam proses pembelajaran antara lain yaitu (1) Alat peraga di sekolah masih kurang (2) Guru kurang memahami bagaimana cara menggunakan alat peraga. Hal ini mengakibatkan siswa cenderung menghafalkan konsep-konsep matematika sehingga kemampuan dalam memecahkan masalah sangat kurang. Padahal pada dasarnya, matematika tidak hanya sekadar menghapalkan rumus dan guru memberikan rumus kepada siswa untuk dihapalkan tetapi siswa harus tahu dari mana rumus tersebut ada dan bagaimana cara menggunakannya.

Keenam, siswa jarang senang dengan mata pelajaran matematika sebab mereka menganggap matematika menegangkan, sulit dan kaku. Di kalangan siswa SD, telah berkembang dengan kuat anggapan bahwa matematika kurang menarik sehingga sulit untuk dipahami. Oleh karena itu, guru-guru di SD 4 Puyoh merasa kesulitan dalam mengembangkan kemampuan matematis siswa.

Ketujuh, beberapa guru mengeluh bahwa dalam mengembangkan alat peraga akan membutuhkan banyak biaya. Sebab kebanyakan guru merasa tidak memiliki keahlian dalam membuat alat peraga secara mandiri. Kenyataannya untuk menyediakan alat peraga tidak selalu memerlukan biaya besar, sehingga bisa dilakukan guru secara mandiri. Selanjutnya pelatihan dan pendampingan penggunaan alat peraga matematika secara benar menjadi sangat signifikan untuk dilaksanakan secara terintegrasi dengan pembuatan alat peraga.

$$
\text { Kedelapan, ketidaktepatan }
$$
penggunaan alat peraga juga tidak banyak membantu penanaman konsep, sehingga penggunaan alat peraga tersebut tidak diprioritaskan. Hal tersebut bertolak belakang dengan kenyataan bahwa pembelajaran matematika di SD merupakan pondasi dasar bagi siswa untuk mempelajari matematika maupun mata pelajaran yang membutuhkan keterampilan matematika di tingkat lanjut, sehingga media penunjang pembelajaran harus dipenuhi.

Dari uraian di atas, dapat disimpulkan bahwa guru-guru di SD 4 Puyoh masih membutuhkan pengetahuan tentang pembuatan dan penggunaan media pembelajaran berupa alat peraga pada materi luas daerah belah ketupat dengan pendekatan luas daerah segitiga. Hal tersebutlah yang melatar belakangi keinginan tim pengabdi untuk mengambil alternatif dengan cara mengadakan pengabdian lanjutan mendampingi guru-guru di SD 4 Puyoh dalam membuat dan menggunakan media pembelajaran berupa alat peraga pada materi luas daerah belah ketupat dengan pendekatan luas daerah segitiga. Dengan demikian, tujuan pengabdian lanjutan ini adalah memberikan pendampingan pembuatan dan penggunaan media pembelajaran berupa alat peraga pada materi luas daerah belah ketupat dengan pendekatan luas daerah segitiga. Dengan adanya pengabdian ini, diharapkan dapat sangat menunjang para guru di SD 4 Puyoh dalam meningkatkan kemampuan matematis siswa.

\section{METODE}

Kegiatan pengabdian kepada masyarakat yang dilakukan diperuntukkan bagi guru-guru SD 4 Puyoh. Metode yang digunakan dalam pengabdian adalah metode ceramah, tanya jawab, diskusi, curah pendapat, studi kasus dan penemuan, simulasi dan praktik. Adapun tahapan kegiatan yaitu sebaga berikut

1. Tahap Perencanaan

Kegiatan yang dilakukan adalah sebagai berikut.

a. Studi lapangan dan analisis kebutuhan berdasarkan fakta lapangan guna menentukan solusi permasalahan.

b. Pengumpulan sumber rujukan dan studi literatur.

c. Perijinan kepada sekolah mitra (SD 4 Puyoh ) dengan perjanjian kerja sama pelaksanaan pengabdian

2. Tahap Persiapan

Kegiatan yang dilakukan adalah sebagai berikut

a. Persiapan tempat pengabdian masyarakat di SD 4 Puyoh .

b. Menyiapkan alat dan bahan untuk membuat alat peraga matematika

c. Menyiapkan materi pelatihan

3. Tahap Pelaksanaan

Kegiatan yang dilakukan adalah tim pengabdian memberikan materi pengabdian yakni tentang pembuatan dan penggunaan alat peraga matematika materi luas belah ketupat luas daerah belah ketupat dengan pendekatan luas daerah segitiga.

\section{d. Tahap Follow Up}

Tahap folow up kegiatan pengabdian dilakukan dalam bentuk pendampingan praktik pembuatan produk hasil pengabdian. Adapun produk hasil pengabdian adalah media pembelalajaran berupa alat peraga 
pada materi luas daerah belah ketupat dengan pendekatan luas daerah segitiga.

e. Tahap Simulasi dan Praktik

Pada tahap simulasi, peserta pengabdian melakukan simulasi mengajar matematika SD dengan menggunakan media pembelajaran berupa alat peraga pada materi luas daerah belah ketupat dengan pendekatan luas daerah segitiga. Tim pengabdian bertugas untuk mendampingi dan mengevaluasi kegiatan simulasi yang dilakukan oleh peserta.

f. Tahap Evaluasi

Kegiatan evaluasi ini dilakukan oleh teman sejawat dan tim pengabdi berupa kegiatan saling menilai dan memberi saran, masukan dan penghargaan atas hasil karya produk peserta pengabdian dan kegiatan simulasi serta praktik mengajar menggunakan media pembelajaran berupa alat peraga pada materi luas daerah belah ketupat dengan pendekatan luas daerah segitiga yang dilakukan dari dan oleh peserta pengabdian. Tim pengabdian bertugas melakukan kegiatan evaluasi, menilai, memberi saran, masukan dan penghargaan terkait hasil pengabdian, produk pengabdian, simulasi dan kegiatan praktik mengajar menggunakan media pembelajaran berupa alat peraga pada materi luas daerah belah ketupat.

\section{HASIL DAN PEMBAHASAN}

Pengabdian ini dilaksanakan di SD 4 Puyoh yang berada di Kecamatan Dawe, Kabupaten Kudus dengan alamat lengkapnya di Desa Puyoh RT 02/ RW 5 Kecamatan Dawe, Kabupaten Kudus sekitar $12 \mathrm{~km}$ dari Universitas Muria Kudus. Tahapan kegiatan dalam pengabdian ini secara garis besar terdiri atas: (1) Tahap Perencanaan Kegiatan; (2) Tahap Persiapan Kegiatan; (3)Tahap Pelaksanaan Kegiatan; (4) Tahap Follow Up Kegiatan; (5) Tahap Simulasi dan Praktik Kegiatan; dan (6) Tahap Evaluasi Kegiatan. Berikut ini adalah uraian tahapan-tahapan kegiatan tersebut.

\section{A. TAHAP PERENCANAAN KEGIATAN}

Pada tahap ini, tim pengabdian Universitas Muria Kudus melakukan studi lapangan dengan cara observasi dan wawancara baik kepada guru N 4 Puyoh maupun kepala sekolah di SD tersebut. Dari hasi studi lapangan tersebut diperoleh kesimpulan bahwa guru-guru memerlukan bantuan dalam memilih strategi maupun media pembelajaran untuk meningkatkan kemampuan matematis siswa sehingga kemampuan tersebut dapat berkembang secara optimal khususnya pada materi matematika.

Setelah dikaji dan dianalis melalui pengumpulan sumber rujukan dan studi literatur tentang masalah yang dialami oleh guru-guru di SD 4 Puyoh, tim pengabdian Universitas Muria Kudus berniat melakukan pengabdian dalam bentuk memberikan bantuan kepada guru-guru SD di sekolah tersebut dengan melakukan pengabdian berupa pelatihan dan pendampingan penyusunan media pembelajaran berupa alat peraga matematika pada luas daerah belah ketupat dengan pendekatan luas daerah segitiga. Dokumentasi kegiatan tersebut ditunjukkan pada Gambar 1 berikut.

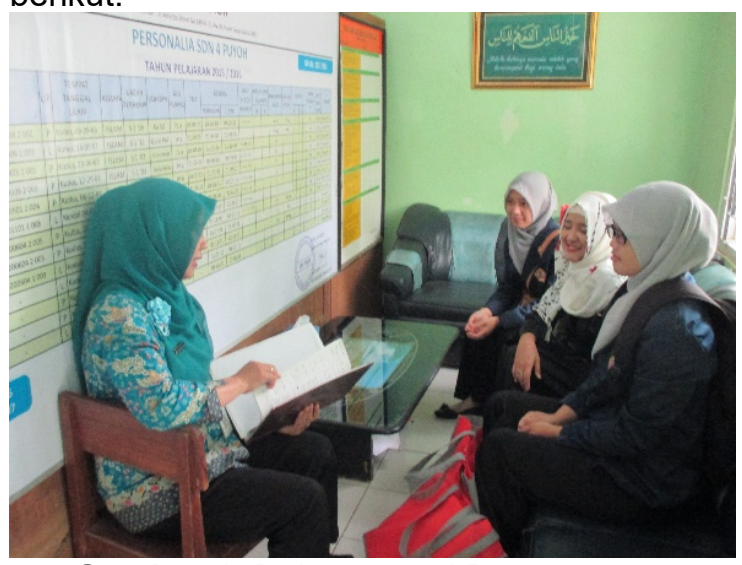

Gambar 1. Dokumentasi Perencanaan

Kegiatan Pengabdian pada Masyarakat

\section{B. TAHAP PERSIAPAN KEGIATAN}

Pada tahap persiapan pengabdian, tim pengabdian Universitas Muria Kudus melakukan persiapan sebagai berikut.

1. Persiapan dan pembuatan materi pelatihan dan pendampingan yang akan ditransfer kepada guru-guru di SD 4 Puyoh. Materi pelatihan disajikan dalam bentuk handout yang terdiri dari

a. Materi teori-teori belajar content materi yaitu teori belajar: (1) Piaget; (2) Ausubel; (3) Vygotsky; (4) Jerome Bruner; dan (5)Van Hiele

b. Media pembelajaran berupa alat peraga.

2. Persiapan perangkat dan kelengkapan pengabdian antara lain pembuatan dan pemasangan banner, alat tulis, dan lain-lain. 
3. Persiapan tempat pengabdian di SD 4 Puyoh.

Adapun gambar 2 berikut adalah gambar kegiatan persiapan pengabdian di SD 4 Puyoh.

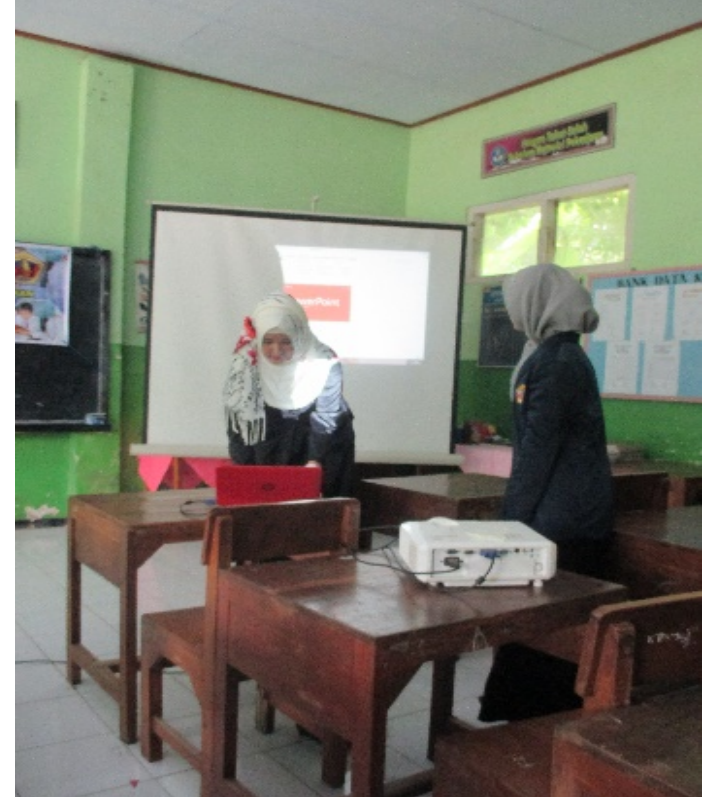

Gambar 2. Dokumentasi Persiapan Kegiatan Pengabdian pada Masyarakat

\section{TAHAP PELAKSANAAN KEGIATAN}

Pada tahap pelaksanaan tim pengabdian memberikan pelatihan dan pendampingan dalam bentuk kegiatan sebagai berikut.

1. Sosialisasi dan workshop materi teoriteori belajar.

Adapun gambar 3 berikut merupakan gambar pelaksanaan kegiatan sosialisasi dan workshop materi teori-teori belajar di SD 4 Puyoh.

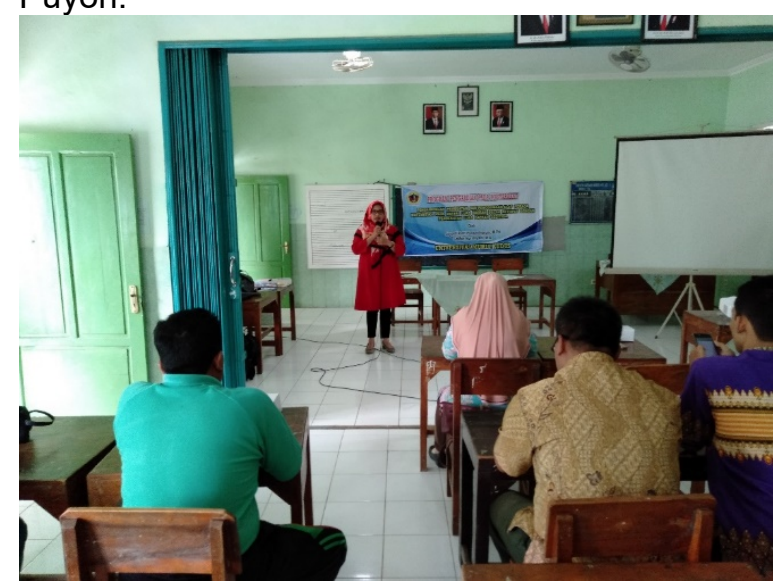

Gambar 3. Dokumentasi Sosialisasi dan Workshop Materi Teori-Teori Belajar

2. Sosialisasi dan workshop materi media pembelajaran berupa alat peraga

Adapun gambar 4 adalah gambar pelaksanaan kegiatan sosialisasi dan workshop materi media pembelajaran berupa alat peraga di SD 4 Puyoh.

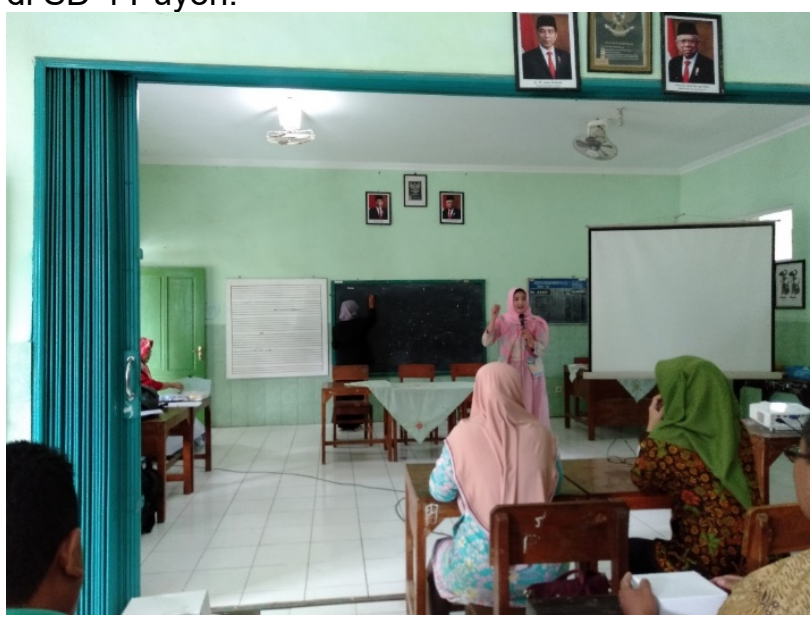

Gambar 4. Dokumentasi Sosialisasi dan Workshop Materi Media Pembelajaran Berupa Alat Peraga

\section{TAHAP FOLLOW UP KEGIATAN}

Tahap folow up kegiatan pengabdian dilakukan dalam bentuk pendampingan praktik pembuatan produk hasil pengabdian. Adapun produk hasil pengabdian adalah sebagai berikut.

1. Produk media pembelajaran berupa alat peraga matematika pada luas daerah belah ketupat dengan pendekatan luas daerah segitiga.

2. Inovasi pembelajaran matematika SD menggunakan media pembelajaran berupa alat peraga matematika pada luas daerah belah ketupat dengan pendekatan luas daerah segitiga yang terwujud dalam simulasi dan praktik mengajar.

Adapun gambar 5 merupakan kegiatan follow up kegiatan pengabdian di SD 4 Puyoh.

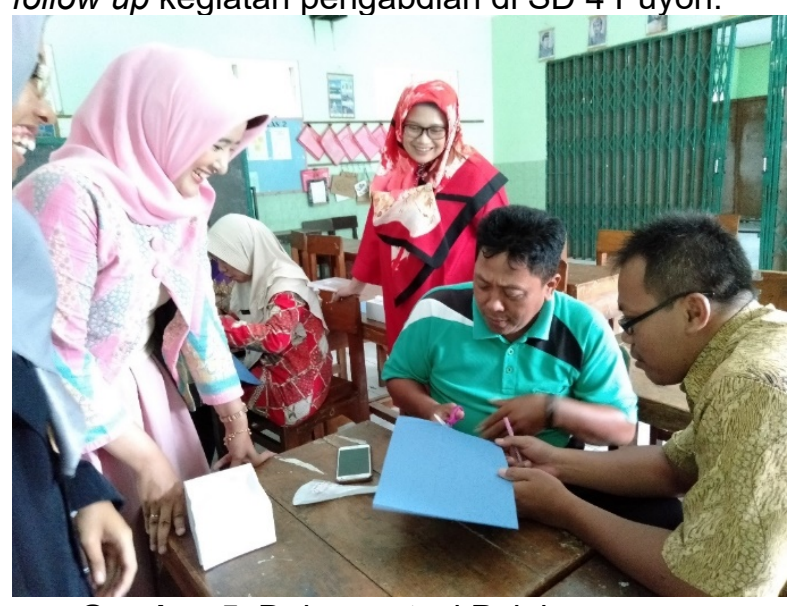

Gambar 5. Dokumentasi Pelaksanaan Kegiatan Follow up Pengabdian

\section{E. TAHAP SIMULASI KEGIATAN}

Pada tahap simulasi, peserta pengabdian melakukan simulasi mengajar 
matematika SD dengan menggunakan media pembelajaran berupa alat peraga matematika pada luas daerah belah ketupat dengan pendekatan luas daerah segitiga di depan teman sejawat dan tim pengabdian. Tim pengabdian bertugas mendampingi dan mengevaluasi kegiatan simulasi yang dilakukan oleh peserta. Gambar 6 berikut merupakan dokumentasi pada tahap simulasi kegiatan.

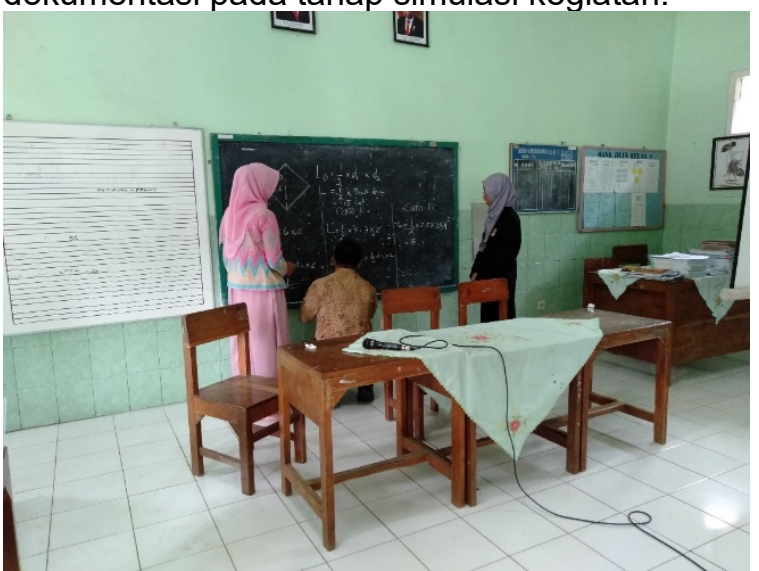

Gambar 6. Dokumentasi Tahap Simulasi

\section{F. TAHAP EVALUASI KEGIATAN}

Evaluasi pada kegiatan pengabdian ini akan dilaksanakan pada dua tahapan evaluasi, yaitu:

1. Evaluasi oleh teman sejawat peserta pelatihan

Kegiatan evaluasi ini dilakukan oleh teman sejawat berupa kegiatan saling menilai dan memberi saran, masukan dan penghargaan atas hasil karya produk peserta pelatihan dan kegiatan simulasi serta praktik mengajar menggunakan media pembelajaran berupa alat peraga matematika pada luas daerah belah ketupat dengan pendekatan luas daerah segitiga yang dilakukan dari dan oleh peserta pengabdian.

2. Evaluasi hasil pelatihan dan pendampingan oleh tim pengabdian

Tim pengabdian melakukan kegiatan evaluasi, menilai, memberi saran, masukan dan penghargaan terkait hasil pelatihan, produk pelatihan, simulasi dan kegiatan praktik mengajar matematika SD menggunakan media pembelajaran berupa alat peraga matematika pada luas daerah belah ketupat dengan pendekatan luas daerah segitiga yang dilakukan dan dibuat oleh peserta pengabdian.

Dari hasil evaluasi, diperoleh bahwa kegiatan pendampingan penyusunanmedia pembelajaran berupa alat peraga matematika pada luas daerah belah ketupat dengan pendekatan luas daerah segitiga bagi guru SD 4 Puyoh berjalan dengan lancar, aktif, kreatif, efektif dan menyenangkan. Guru-guru yang terlibat memperoleh pengetahuan, pengalaman dan gambaran tentang:

a. Strategi (teori) yang dapat digunakan untuk meningkatkan kemampuan matematis siswa;

b. Media pembelajaran yang dapat digunakan untuk meningkatkan kemampuan matematis siswa;

c. Penyusunan media pembelajaran berupa alat peraga matematika pada luas daerah belah ketupat dengan pendekatan luas daerah segitiga;

d. Simulasi dan praktik pembelajaran dengan menggunakan media pembelajaran berupa alat peraga matematika pada luas daerah belah ketupat dengan pendekatan luas daerah segitiga.

e. Guru-guru memperoleh tambahan pengalaman dalam menerapkan inovasi pembelajaran matematika SD menggunakan media pembelajaran berupa alat peraga matematika pada luas daerah belah ketupat dengan pendekatan luas daerah segitiga untuk meningkatkan kemampuan matematis siswa. Hasil dari kegiatan pengabdian juga dapat digunakan sebagai tambahan referensi dalam memilih media pembelajaran yang efektif untuk meningkatkan kemampuan matematis siswa.

Adapun gambar 7 merupakan dokumentasi tahap evaluasi kegiatan pengabdian di SD 4 Puyoh.

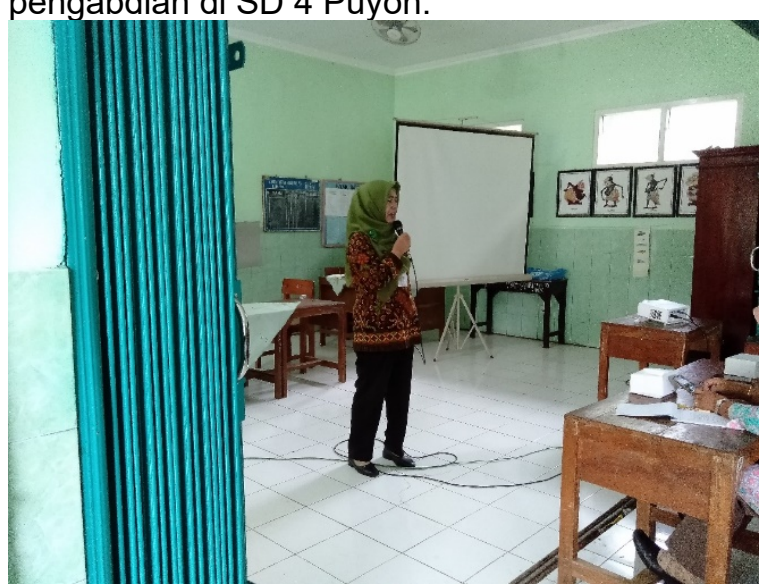

Gambar 7. Dokumentasi Kegiatan Evaluasi

\section{SIMPULAN DAN SARAN}

Adapun hasil dari kegiatan pengabdian kepada masyarakat ini yaitu guru di SD 4 Puyoh dapat mengenal dan memahami strategi (teori) yang dapat digunakan untuk meningkatkan 
kemampuan matematis, memperoleh tambahan pengalaman dalam menerapkan inovasi pembelajaran matematika SD menggunakan media pembelajaran berupa alat peraga matematika pada luas daerah belah ketupat dengan pendekatan luas daerah segitiga untuk meningkatkan kemampuan matematis. Selain itu, pengalaman yang diperoleh dari kegiatan pengabdian dapat digunakan sebagai tambahan referensi dalam memilih media pembelajaran yang efektif untuk meningkatkan kemampuan matematis siswa.

\section{DAFTAR RUJUKAN}

Al-Tabany, T. I. B. (2014). Mendesain model pembelajaran inovatif, progresif, dan kontekstual. In Prenadamedia Group.

Hamalik, O. (1986). Media Pendidikan. Citra Aditya Bakti.

Hudojo, H. (1988). Mengajar Belajar Matematika. Departemen Pendidikan dan Kebudayaan.

Mathematics, N. C. of T. of. (2000). Curriculum and Evaluation Standards for School Mathematics. National Council of Teachers of Mathematics.

Mulyasa, E. (2005). Menjadi guru profesional menciptakan pembelajaran kreatif dan menyenangkan. In Bandung: Remaja Rosdakarya.

Olkun. (2005). Geometric Explorations With Dynamic Geometry Applications Based On Van Hiele Levels. http://www.cimt.plymouth.ac.uk/journal/ olkun.pdf

Sardiyanah, S. (2020). BELAJAR DAN FAKTOR YANG MEMPENGARUHINYA. Jurnal AlQalam: Jurnal Kajian Islam \& Pendidikan. https://doi.org/10.47435/alqalam.v7i1.187

Sugiarto., Hidayah, I. (2006). Workshop Pendidikan Matematika 1. Jurusan Matematika FMIPA UNNES.

Suherman, E. dkk. (2011). Strategi Pembelajaran Matematika Kontemporer. Bandung: PT Remaja Rosdakarya.

Sumarmo, U. (2013). Handout Mata Kuliah Evaluasi Pembelajaran Matematika. SPs UPI. 